\title{
Emulsifying and Gelling Properties of Pork Myofibrillar Protein as Affected by Various $\mathrm{NaCl}$ Levels and $\mathrm{pH}$ Values
}

\author{
Ho Sik Jang and Koo Bok Chin* \\ Department of Animal Science and Functional Foods Research Institute, Chonnam National University, \\ Gwangju 500-757, Korea
}

\begin{abstract}
The effects of various $\mathrm{NaCl}$ levels $(0,0.3$, and $0.6 \mathrm{M})$ and $\mathrm{pH}$ values (pH 5.0, 5.5, 6.0, and 6.5) on the emulsifying and gelling properties of pork myofibrillar protein (MP) were assessed. The emulsion stability index (ESI), emulsifying activity index (EAI), and creaming index were measured at a 1:20 ratio of MP to corn oil. The EAI and ESI of pork MP showed maximum values at $\mathrm{pHs} 6.0$ and 6.5 and at $0.3 \mathrm{M} \mathrm{NaCl}$, resulting in better emulsion properties. Additionally, the cooking yield (CY) and gel strength (GS) of emulsified MP gel were measured at an MP: corn oil ratio of 1: 2; GS increased with increasing levels of salt. At $0.6 \mathrm{M} \mathrm{NaCl}$, GS decreased with decreasing $\mathrm{pH}$ from 5.5 to 6.5. GS and gelling properties were optimal at pH 5.5 in $0.6 \mathrm{M}$ salt. The highest $\mathrm{CY}$ was observed at $0.6 \mathrm{M} \mathrm{NaCl}$, regardless of the $\mathrm{pH}$ value. However, increasing $\mathrm{pH}$ increased $\mathrm{CY}$ at salt levels of 0 and $0.3 \mathrm{M}$. These results indicate that $\mathrm{NaCl}$ and $\mathrm{pH}$ profoundly affected the emulsified MP system. Future work will be conducted on the rheological properties of the pork emulsified system as affected by adding non-meat protein.
\end{abstract}

Key words: emulsion, myofibrillar protein, salt level, $\mathrm{pH}$ value, gelling properties

\section{Introduction}

Myofibrillar proteins (MPs) contribute to the characteristics of muscle proteins. In particular, they improve the texture of heat-induced gels and play an important role in meat processing (Ionescu et al., 2008). Emulsion is an important technology in meat processing, and affects product quality, such as flavor and texture (Ramirez-Suarez and Xiong, 2003). It has been previously reported that the hydrophobic myosin head combined with fat, whereas the hydrophilic myosin tail combined with water (Park et al., 2003). Thus, MP would be expected to contribute to emulsifying properties - in particular, emulsifying activity and emulsion stability. Currently, consumers tend to prefer emulsified meat products that contain as low a fat content as possible, although fat is an important factor in food palatability, and also stabilizes emulsion systems. Destabilization of emulsion can occur through sequential mechanisms - generally, creaming, sedimentation, flocculation, coalescence, and phase separation (McClements,

\footnotetext{
*Corresponding author: Koo Bok Chin, Department of Animal Science, Chonnam National University, Gwangju 500-757, Korea. Tel: 82-62-530-2121, Fax: 82-62-530-2129, E-mail: kbchin (a)chonnam.ac.kr
}

1994). Changes in $\mathrm{pH}$ and salt levels have been implicated as possible factors that affect emulsion stability (Thakur et al., 2006). It has also been previously reported that changes in $\mathrm{pH}$ affected gelling properties, emulsifying properties, and water holding capacity (Bertram et al., 2004; Manoi and Rizvi, 2009). Moreover, the addition of salt improves the solubility of meat batter, resulting in improvements in gelling and emulsifying properties (Guzey and McClements, 2006). Therefore, this study was carried out to evaluate the effects of various $\mathrm{NaCl}$ levels $(0,0.3$, and $0.6 \mathrm{M})$ and $\mathrm{pH}$ values $(\mathrm{pH} 5.0,5.5,6.0$, and 6.5) on the emulsifying and gelling properties of pork MP.

\section{Materials and Methods}

\section{Materials}

Pork loin (crossbreed of Landrace $\times$ Yorkshire $\times$ Duroc, 6 months old hogs), at pH 5.5-5.7 were collected from the M. longissimus dorsi carcasses at $24 \mathrm{~h}$ post-mortem. All fat and connective tissues were trimmed out and cut into a cubic shape $\left(1 \mathrm{~cm}^{3}\right)$. The meat cubes were portioned at approximately $200 \mathrm{~g}$ before stored at $-70^{\circ} \mathrm{C}$ under vacuum until analyzed. 


\section{Extraction of myofibrillar protein (MP)}

Myofibrillar protein isolate (MPI) was prepared by the previous method (Hong and Chin, 2010) from the pork loin by washing three times with 4 volumes $(\mathrm{v} / \mathrm{w})$ of 0.1 $\mathrm{M} \mathrm{NaCl}, 50 \mathrm{mM} \mathrm{NaH}_{2} \mathrm{PO}_{4}$ buffer (pH 6.25), followed by washing with 8 volumes $(\mathrm{v} / \mathrm{w})$ of $0.1 \mathrm{M} \mathrm{NaCl}(\mathrm{pH} 6.25)$. The MP was adjusted to targeted $\mathrm{pH}$ values $(5.0,5.5,6.0$, and 6.5) using $1 \mathrm{~N} \mathrm{HCl}$ or $\mathrm{NaOH}$ (Hong and Chin, 2010) and centrifuged for $15 \mathrm{~min}$ at $3,000 \mathrm{~g}$ at $4^{\circ} \mathrm{C}$ (Beckman, USA). Protein concentrations were determined by the Biuret method (Gornall et al., 1949).

\section{Emulsion preparation and properties}

The emulsion was prepared at different $\mathrm{pH}$ values (5.0, 5.5, 6.0, and 6.5) and $\mathrm{NaCl}$ levels $(0,0.3$, and $0.6 \mathrm{M})$ using an MP : corn oil ratio of 1:20. The mixtures were homogenized for 2 min using an Ultra-Turrax (T25 Basic, Ika Works, Inc., USA) at 13,000 rpm. The emulsion stability index (ESI) and emulsifying activity index (EAI) were measured by the turbidimetric method (Pearce and Kinsella, 1978). The homogenates $(2.7 \mathrm{~mL})$ were mixed with $0.3 \mathrm{~mL}$ of $0.1 \%$ sodium dodecyl sulfate (SDS). The absorbance of diluted emulsion was measured at $500 \mathrm{~nm}$ and reported as the initial absorbance $\left(\mathrm{A}_{0}\right)$. Thereafter, the samples were maintained for $3 \mathrm{~h}$ at $20^{\circ} \mathrm{C}$ prior to determining the incubated absorbance $\left(\mathrm{A}_{\mathrm{t}}\right)$. The emulsifying activity index was calculated in accordance with the equation shown below:

$$
\text { EAI }\left(\mathrm{m}^{2} / \mathrm{g}\right)=\frac{2 \times 2.303}{\Phi \times \mathrm{C} \times 10.000} \times \mathrm{A}_{500} \times \mathrm{D}
$$

$\Phi$ is the volume of oil, $\mathrm{C}$ is the protein concentration $(\mathrm{g} / \mathrm{mL})$, and $\mathrm{D}$ is the dilution factor

$$
\text { ESI }(\%)=\frac{A_{t}}{A_{0}} \times 100
$$

$\mathrm{A}_{0}$ and $\mathrm{A}_{\mathrm{t}}$ are the absorbance values at $500 \mathrm{~nm}$ at 0 and $3 \mathrm{~h}$, respectively.

\section{Creaming index}

The creaming index confirms emulsion stabilized of MP by the method (Ionescu et al., 2008). Emulsions were transferred into test tubes and stored for $24 \mathrm{~h}$ at room temperature. The creaming index was determined as in equation (3):

$$
\text { Creaming index }(\%)=\frac{\mathrm{H}_{\mathrm{s}}}{\mathrm{H}_{\mathrm{t}}} \times 100
$$

in which $\mathrm{H}_{\mathrm{t}}$ is the height of the initial emulsion, and Hs is the height of the separated emulsion.

\section{Cooking yield and gel strength}

The emulsified MP was prepared at different $\mathrm{pH}$ values (5.0, 5.5, 6.0, and 6.5) and $\mathrm{NaCl}$ concentrations (0, 0.3, and $0.6 \mathrm{M}$ ) at $3 \% \mathrm{MP}$. The ratio of MP and corn oil was controlled at 1: 2 . The mixture was cooked in a water bath heated from 5 to $80^{\circ} \mathrm{C}$ for about $30 \mathrm{~min}$. The cooking yield was calculated from the equation:

$$
\text { Cooking yield }=\left(\mathrm{W}_{\mathrm{a}} / \mathrm{W}_{\mathrm{I}}\right) \times 100
$$

in which $\mathrm{W}_{\mathrm{a}=}$ the weight of the remaining gels. $\mathrm{W}_{\mathrm{I}}$ is the weight of the initial gels.

In order to measure the gel strength of the emulsified MP samples (12 mm diameter and $20 \mathrm{~mm}$ height), a puncture test was conducted using an Instron (model 3344, Instron Corporation, USA) equipped with a stainless probe $($ diameter $=9 \mathrm{~mm})$; the head speed was controlled at $50 \mathrm{~mm} / \mathrm{min}$.

\section{Statistical analysis}

Data were analyzed by two-way ANOVA using the SPSS statistical software package, version 17.0. The main factors included $\mathrm{pH}$ values $(5.0,5.5,6.0$, and 6.5$)$ and $\mathrm{NaCl}$ concentrations $(0,0.3$, and $0.6 \mathrm{M})$. Differences among the means were compared using Duncan's multiple range test. Each measurement was conducted in duplicate and the entire experiment was replicated three times.

\section{Results and Discussion}

\section{Emulsifying properties}

The effects of salt concentrations and $\mathrm{pH}$ values on the EAI of emulsions prepared with myofibrillar protein (MP) and corn oil mixtures are shown in Table 1. The EAI of emulsified pork MP did not differ among various $\mathrm{pH}$ values at $0 \mathrm{M}$ salt $(p>0.05)$. EAIs at $0.3 \mathrm{M}$ were increased when $\mathrm{pHs}$ were increased, and the highest value was found at the $\mathrm{pH}$ values of either 6.0 or 6.5 (Table 1). It has been reported that the isoelectric point (PI) of MP was approximately pH 5.2 (Huff-Lonergan and Lonergan, 2005; Westphalen et al., 2005). Additionally, EAI seems to have the lowest value at the pI of meat protein, due to the repulsion of proteins induced by reduced charges. At $\mathrm{pH}$ 5.0, the EAI of emulsified MP increased with increasing salt concentrations (Table 1). These results suggest that the increased ionic strength at $\mathrm{pH} 5.0$ and 5.5 could change the charge of the proteins, thereby the results may 
improve emulsifying properties. However, the MP and corn oil mixtures at $\mathrm{pH} 6.0$ and 6.5 showed the highest EAI values at a $0.3 \mathrm{M}$ salt, when compared to values observed at 0 or $0.6 \mathrm{M}$ salt. High salt levels $(0.6 \mathrm{M}$ salt) may promote electrostatic interaction by charge neutralization at $\mathrm{pH}$ higher than 6.0. Thus, the EAI was affected by salt and $\mathrm{pH}$ which they were interacted. Agyare et al. (2009) reported that an increase in ionic strength did not influence emulsion properties. Zhang et al. (2009) concluded that $\mathrm{NaCl}$ played an important role in emulsion properties, by two mechanisms. First, $\mathrm{NaCl}$ reduces electrostatic repulsion. Second, high salt levels may alter the hydrophobic interactions between non-polar groups. These results explain why EAI varied, depending on various $\mathrm{NaCl}$ and $\mathrm{pH}$ combinations in this study.

Although ESI values did not differ at lower $\mathrm{pH}$ values (pH 5.0 and 5.5), regardless of three different salt levels (Table 1), those were values increased at $\mathrm{pH} 6.0$ and 6.5 in $0.3 \mathrm{M}$ salt; this suggests that the optimal conditions would be a pH higher than 6.0 at a salt concentration of $0.3 \mathrm{M}$. Thus, ESI values were unaffected by high salt levels. This may be attributable to the collision of particles at high salt levels $(>0.3 \mathrm{M})$. An increased cohesiveness of protein did not allow the protein to envelop fat globules and accelerate the phase separation by gravity (McClement, 1999).

The creaming index $(\mathrm{CI})$ tended to be higher with in-

Table 1. Emulsifying properties of pork myofibrillar protein as affected by various $\mathrm{pH}$ and salt levels

\begin{tabular}{|c|c|c|c|}
\hline EAI $\left(\mathrm{m}^{2} / \mathrm{g}\right)^{*}$ & $0 \mathrm{M}$ & $0.3 \mathrm{M}$ & $0.6 \mathrm{M}$ \\
\hline pH 5.0 & $5.5 \pm 0.8^{\mathrm{xB}}$ & $5.5 \pm 0.5^{\mathrm{yB}}$ & $7.9 \pm 0.9^{\mathrm{xA}}$ \\
\hline pH 5.5 & $6.0 \pm 0.3^{\mathrm{xA}}$ & $7.8 \pm 0.5^{\mathrm{yA}}$ & $6.5 \pm 2.5^{\mathrm{xyA}}$ \\
\hline pH 6.0 & $6.1 \pm 0.6^{\mathrm{xB}}$ & $12.4 \pm 0.2^{\mathrm{xA}}$ & $3.7 \pm 0.3^{\mathrm{yC}}$ \\
\hline $\mathrm{pH} 6.5$ & $6.7 \pm 0.6^{\mathrm{xB}}$ & $10.8 \pm 2.4^{\mathrm{xA}}$ & $4.4 \pm 1.3^{\mathrm{yB}}$ \\
\hline $\operatorname{ESI}(\%)^{* *}$ & $0 \mathrm{M}$ & $0.3 \mathrm{M}$ & $0.6 \mathrm{M}$ \\
\hline pH 5.0 & $39.2 \pm 2.6^{\mathrm{xA}}$ & $34.4 \pm 2.8^{\mathrm{zA}}$ & $40.6 \pm 4.9^{\mathrm{xA}}$ \\
\hline pH 5.5 & $38.6 \pm 1.5^{\mathrm{xA}}$ & $44.8 \pm 2.2^{\mathrm{yA}}$ & $42.0 \pm 8.4^{\mathrm{xA}}$ \\
\hline $\mathrm{pH} 6.0$ & $37.6 \pm 2.6^{\mathrm{xB}}$ & $56.3 \pm 0.6^{\mathrm{xA}}$ & $34.7 \pm 6.3^{\mathrm{xB}}$ \\
\hline $\mathrm{pH} 6.5$ & $41.0 \pm 2.7^{\mathrm{xB}}$ & $53.9 \pm 7.5^{\mathrm{xA}}$ & $43.1 \pm 2.4^{\mathrm{xB}}$ \\
\hline CI $(\%)^{* * *}$ & $0 \mathrm{M}$ & $0.3 \mathrm{M}$ & $0.6 \mathrm{M}$ \\
\hline pH 5.0 & $62.7 \pm 3.2^{\mathrm{xA}}$ & $69.3 \pm 4.8^{\mathrm{yA}}$ & $67.4 \pm 7.3^{\mathrm{yA}}$ \\
\hline pH 5.5 & $62.0 \pm 1.8^{\mathrm{xB}}$ & $58.4 \pm 2.4^{\mathrm{zB}}$ & $92.9 \pm 12.1^{\mathrm{xA}}$ \\
\hline $\mathrm{pH} 6.0$ & $57.9 \pm 0.4^{\mathrm{yB}}$ & $59.7 \pm 2.0^{\mathrm{zB}}$ & $100^{\mathrm{xA}}$ \\
\hline pH 6.5 & $54.9 \pm 1.9^{\mathrm{yB}}$ & $97.0 \pm 5.1^{\mathrm{xA}}$ & $100^{\mathrm{xA}}$ \\
\hline \multicolumn{4}{|c|}{$\begin{array}{l}\text { *EAI, emulsion activity index; } * * \text { ESI, emulsion stability index; } \\
{ }^{* * *} \text { CI, creaming index } \\
\text { A-C Means } \pm \text { SD with same superscript in a same raw are not differ- } \\
\text { ent }(p>0.05) \text {. } \\
\text { ferent }(p>0.05) \text {. }\end{array}$} \\
\hline
\end{tabular}

creased $\mathrm{pH}$ and salt level, resulting in an optimal creaming index at both $\mathrm{pH} 6.0$ and 6.5 at a salt level of $0.6 \mathrm{M}$ salt level (Table 1). These results indicated that the optimal conditions for EAI and ESI were at $\mathrm{pH} 6.0$ or 6.5 at a salt level of $0.3 \mathrm{M}$. A combination of higher $\mathrm{pH}$ and salt proved better for the CI. Creaming identified the separation of oil droplets by different densities, after which the fat globules have to rise to the surface. Creaming also contributes to the cohesive properties of protein particles and then droplets stable against coalescence maintain integrity for better emulsion stability (Robins et al., 2002). Thus, emulsion stability affects creaming and cohesion.

\section{Cooking yield and gel strength}

The gel strength of emulsified pork MP was acceptable at most $\mathrm{pH}$ levels with salt level at $0.6 \mathrm{M} \mathrm{NaCl}$, except at pH 5.0 (Fig. 1). Thus, the increased salt level improved the gelling properties of emulsified pork MP. ESI and EAI values at a salt level of $0.6 \mathrm{M}$ were lower than those at a salt level of $0.3 \mathrm{M}$, whereas gel strength at $0.6 \mathrm{M}$ salt was higher than that at $0.3 \mathrm{M}$ salt. These results indicated that the maximum $\mathrm{CY}$ was achieved at $\mathrm{pH} 5.5$ in $0.6 \mathrm{M}$ salt or at $\mathrm{pH} 6.0$ and 6.5 at salt level higher than $0.3 \mathrm{M}$. The acceptable gel strength was noted at higher salt level ( $0.6 \mathrm{M}$ salt), regardless of $\mathrm{pH}$ values $(\mathrm{pH}>5.5)$.

CYs of the pork emulsified MP were improved at $\mathrm{pH}$ 6.0 and 6.5 at salt levels of either 0.3 or $0.6 \mathrm{M}$ (Fig. 2). Additionally, the $\mathrm{CY}$ at $\mathrm{pH} 5.5$ was also improved with higher salt level $(0.6 \mathrm{M})$. Although WHC was lowest at the isoelectric point (PI) of protein, increased salt levels improved WHC (Westphalen et al., 2005). Thus, CY at high salt level $(0.6 \mathrm{M})$ improved, regardless of the $\mathrm{pH}$ value. However, that value was higher at $\mathrm{pH} 6.5$ than at $\mathrm{pH}$

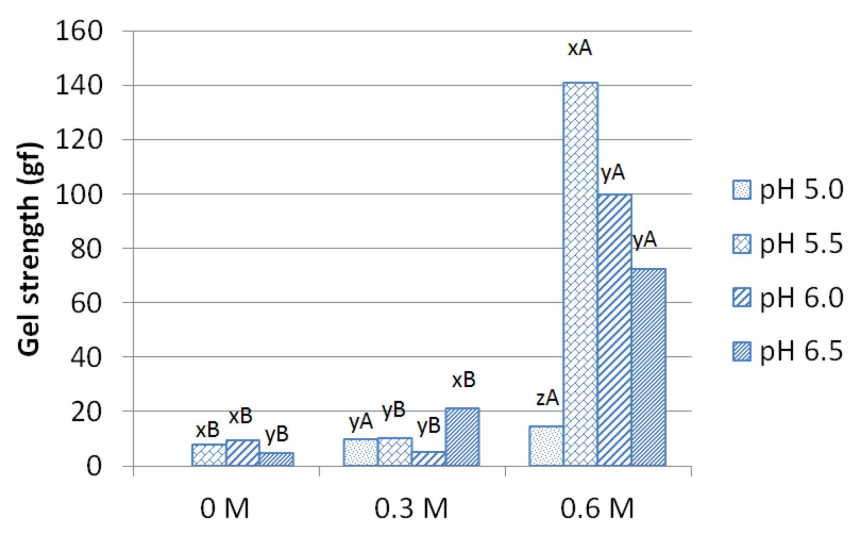

Fig. 1. Gel strength (gf) of pork myofibrillar protein as affected by various $\mathbf{p H}$ and salt levels. ${ }^{\mathrm{A}, \mathrm{B}}$ Same superscript in a same row are not different $(p>0.05) .{ }^{\mathrm{x}-\mathrm{z}}$ Same superscript in a same column are not different $(p>0.05)$. 


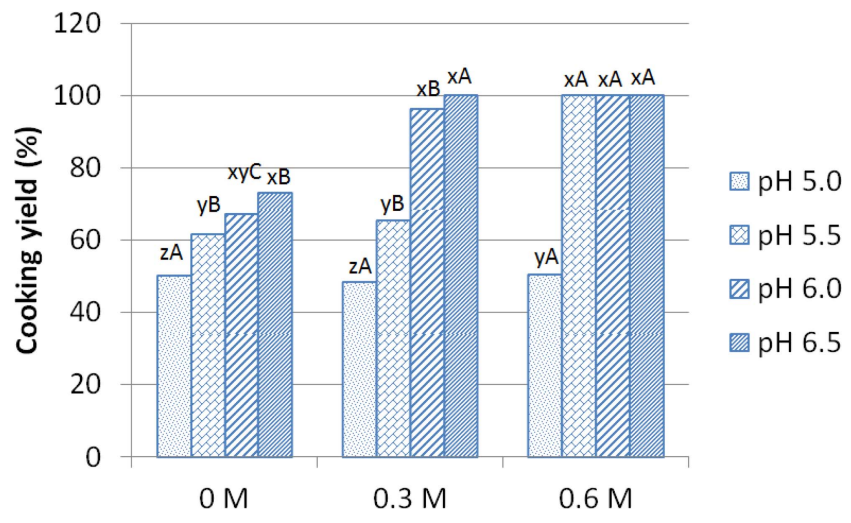

Fig. 2. Cooking yield (\%) of pork myofibrillar protein as affected by various $\mathrm{pH}$ and salt levels. ${ }^{\mathrm{A}-\mathrm{C}}$ Same superscript in a same row are not different $(p>0.05)$. ${ }^{\mathrm{x}-\mathrm{z}}$ Same superscript in a same column are not different $(p>0.05)$.

5.5 in a salt value of $0.3 \mathrm{M}$. This was because high $\mathrm{pH}$ levels increased the negative charges of proteins (Guzey and McClements, 2006).

The optimum condition to obtain acceptable EAI and ESI of emulsified pork MP was $\mathrm{pH}$ values of 6.0 or 6.5 in a salt level of $0.3 \mathrm{M} \mathrm{NaCl}$. However, higher $\mathrm{pH}$ and salt levels were better for the creaming index. The best combination for higher $\mathrm{CY}$ was at $\mathrm{pH} 6.5$ and $0.3 \mathrm{M}$ salt, and $\mathrm{pH}$ values higher than $\mathrm{pH} 5.5$ and $0.6 \mathrm{M}$ salt. Acceptable gel strength was observed at $\mathrm{pH} 6.5$ and $0.3 \mathrm{M}$ or higher salt level $(\mathrm{pH}>5.5)$, regardless of $\mathrm{pH}$ values.

\section{Acknowledgement}

This study was supported by Chonnam National University, 2009.

\section{References}

1. Agyare, K. K., Addo, K., and Xiong, Y. (2009) Emulsifying and foaming properties of transglutaminase-treated wheat gluten hydrolysate as influenced by $\mathrm{pH}$, temperature and salt. Food Hydrocoll. 23, 72-81.

2. Bertram, H. C., Kristensen, M., and Andersen, H. J. (2004) Functionality of myofibrillar proteins as affected by $\mathrm{pH}$, ionic strength and heat treatment - a low-field NMR study. Meat Sci. 68, 249-256.

3. Gornall, A. G., Bardawill, C. Y., and David, M. M. (1949)
Determination of serum proteins by means of the biuret reaction. J. Biol. Chem. 177, 751-756.

4. Guzey, D. and McClements, D. J. (2006) Formation, stability and properties of multilayer emulsions for application in the food industry. Adv. Colloid Interface Sci. 128-130, 227-248.

5. Hong, G. P. and Chin, K. B. (2010) Effects of microbial transglutaminase and sodium alginate on cold-set gelation of porcine myofibrillar protein with various salt levels. Food Hydrocoll. 24, 444-451.

6. Huff-Lonergan, E. and Lonergan, S. M. (2005) Mechanisms of water-holding capacity of meat: The role of postmortem biochemical and structural changes. Meat Sci. 71, 194-204.

7. Ionescu, A., Aprodu, I., Daraba, A., and Porneala, L. (2008) The effects of transglutaminase on the functional properties of the myofibrillar protein concentrate obtained from beef heart. Meat Sci. 79, 278-284.

8. Manoi, K. and Rizvi, S. S. H. (2009) Emulsification mechanisms and characterizations of cold, gel-like emulsions produced from texturized whey protein concentrate. Food Hydrocoll. 23, 1837-1847.

9. McClements, D. J. (1999) Food emulsions. CRC Press, Boca Racton, FL, USA.

10. Park, H. G., Oh, H. R., Ha, J. G., Kang, J. G., Lee, G. T., and Chin, K. B. (2003) The science and technology of meat and meat products. Sun Jin Publishing Co., Seoul, Korea, pp. 248-250.

11. Pearce, K. N. and Kinsella, J. E. (1978) Emulsifying properties of proteins: Evaluation of a turbidimetric technique. $J$. Agric. Food Chem. 26, 716-723.

12. Ramirez-Suarez, J. C. and Xiong, Y. L. (2003) Rheological properties of mixed muscle/nonmuscle protein emulsions treated with transglutaminase at two ionic strengths. Intl. J. Food Sci. Technol. 38, 777-785.

13. Robins, M. M., Watson, A. D., and Wilde, R. J. (2002) Emulsions-creaming and rheology. Curr. Opin. Colloid Interface Sci. 7, 419-425.

14. Thakur, R. K., Vial, C., and Djelveh, G. (2006) Effect of pH of food emulsions on their continuous foaming using a mechanically agitated column. Innovative Food Sci. Emerging Technol. 7, 203-210.

15. Westphalen, A. D., Briggs, J. L., and Lonergan, S. M. (2005) Influence of $\mathrm{pH}$ in rheological properties of porcine myofibrillar protein during heat induced gelation. Meat Sci. 70, 293-299.

16. Zhang, T., Jiang, B., Mu, W., and Wang, Z. (2009) Emulsifying properties of chickpea protein isolates: Influence of $\mathrm{pH}$ and $\mathrm{NaCl}$. Food Hydrocoll. 23, 146-152.

(Received 2011.7.23/Revised 1st 2011.9.8, 2nd 2011.10.13/ Accepted 2011.10.13) 